\title{
Diet of the giant tadpole Pseudis paradoxa platensis (Anura, Pseudidae) from Argentina
}

\author{
Myriam M. Arias, Paola M. Peltzer, and Rafael C. Lajmanovich \\ Instituto Nacional de Limnología (INALI-CONICET-UNL), José Macias 1933, 3016 - Santo Tomé, Santa Fe \\ (Argentina). E-mails: inali@ceride.gov.ar; paolapeltzer@hotmail.com.
}

Keywords: Pseudis paradoxa platensis, Pseudidae, Anura, tadpole, diet, Argentina.

Pseudis paradoxa platensis is restricted to areas along the Paraguay and Paraná Rivers, from Paraguay, Bolivia and Mato Grosso (Brazil) to northeast of Argentina (Cei 1980). In Argentina, this subspecies has been found in Formosa, Chaco, Corrientes, Misiones and Santa Fe provinces (Frost 1985, Gallardo and Varela de Olmedo 1992). The adults are very aquatic, occurring in semipermanent and permanent ponds (Dixon et al. 1995, Duré and Kehr 2001). In Argentina breeding occurs between November and March. Tadpoles of P. paradoxa platensis reach lengths up to $168 \mathrm{~mm}$ (Bokermann 1967, Emerson 1988). Studies on the biology of this giant tadpole in nature are extremely scarce. This study describes the tadpole diet of $P$. paradoxa platensis and presents some behavior data.

Tadpoles were collected in a semipermanent pond located $30 \mathrm{~km}$ from the city of Corrientes $\left(27^{\circ} 25^{\prime} \mathrm{S}\right.$ - 58 $44^{\circ} \mathrm{W}$, Province of Corrientes, Argentina) during the summer season (December, January and February). The area corresponds to the Oriental Chaqueña phytogeographical region (Carnevali 1994, Burkart et al. 1999). Climatically, this area has a mean annual rainfall of $1100 \mathrm{~mm}$ and a mean annual temperature of $20^{\circ} \mathrm{C}$. The pond area was

Received 10 December 2002

Accepted 30 December 2002
$800 \mathrm{~m}^{2}$ and the water depth was $0.30 \mathrm{~m}$. Macrophytes and the common grasses (Panicum elephantipes, Cynodon dactylon, Eragrostis sp.) were found on its border but there were not aquatic floating plants.

Ten tadpoles were captured with a square fine meshed-net $\left(1 \mathrm{~m}^{2}\right)$ in different locations in the pond and were anaesthetized and fixed according to ASIH and SSAR. (2001) guidelines. The specimens were deposited in the amphibian collection of the National Institute of Limnology (INALI-CONICET-UNL). The total length (snout to the tip of tail) and body length (snout to the end of proctodeal tube) were recorded. Developmental stages were recorded following Gosner (1960). The coiled intestine was then removed and cut into several pieces. Twenty pieces were chosen at random and their contents mixed with $1 \mathrm{ml}$ of water and one drop of erithrocyne. After $24 \mathrm{~h}$ three aliquots of each tadpole intestine sample were analyzed under an optic microscope. To quantify the number of organisms per ml, the Microtransects Drop Method of Lackey (APHA 1976) was followed. For each food item, its numeric frequency $(\mathrm{N})$ and frequency of occurrence (FO) was calculated as percentage based on the total number of quantified food items and the number of intestines analyzed. To determine the trophic diversity (H) Hurtubia's criteria (1973), using Brillouin's formula (1965), was followed. The 
Table 1 - Diet of Pseudis paradoxa platensis tadpoles in a semi-permanent pond in Corrientes Province (Argentina) (n = 10). N, numerical frequency percentage (based on Lackey's method); FO, percentage of occurrence; ni, non-identified; -, non-quantified; $\mathrm{H}^{*}$, mean trophic diversity; $\mathrm{H}_{\mathrm{k}}$, accumulated trophic diversity.

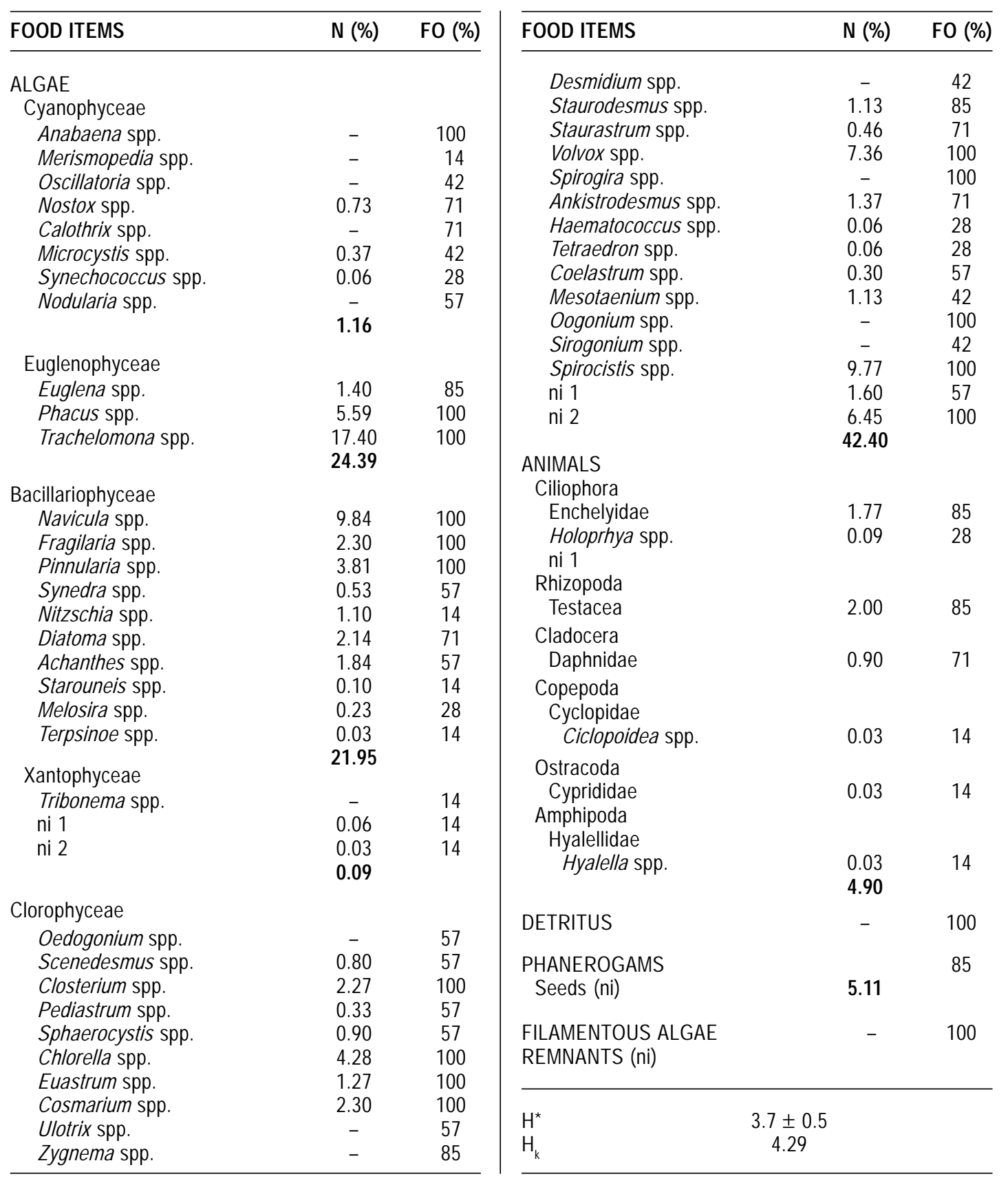


individual estimations of items were summed up at random, which constitutes the accumulated trophic diversity. The mean diversity $\left(\mathrm{H}^{*}\right)$ and accumulated trophic diversity $\left(\mathrm{H}_{\mathrm{k}}\right)$ were calculated.

The development stages of Pseudis paradoxa platensis tadpoles studied ranged from 27 to 31 . These pre-metamorphic tadpoles had an average total length of $62.28 \mathrm{~mm}( \pm$ $3.79)$ and an average body length of $25.8 \mathrm{~mm}$ $( \pm 1.7)$.

The diets of the tadpoles are given in Table 1. Algae are the most abundant types of food ingested; occurring in all intestines examined $(100 \%)$. The most important food items, in terms of numeric frequency, were planktonic algae of the families Clorophyceae (42.4\%) and Euglenophyceae $(24.39 \%)$. The seeds of phanerogams occurred in $85 \%$ of the intestines as well as animal material (also 85\%). The most important animals were Crustacea from the Orders Cladocera, Copepoda, Amphipoda, and Ostracoda. Detritus is also a frequent category in the diets $(100 \%)$. The mean diversity $\left(\mathrm{H}^{*}\right)$ was $3.70( \pm 0,5)$ and accumulated trophic diversity $\left(\mathrm{H}_{\mathrm{k}}\right)$ was 4.29 . Lajmanovich (2000) found similar values for another pseudid tadpole, Lysapsus limellus $\left(\mathrm{H}_{\mathrm{k}}=4.5\right)$ that cohabits the same environments.

Pseudis paradoxa platensis tadpoles are basically omnivorous, feeding mostly on phytoplankton, and supplementing their diets with other types of food, such as zooplankton and seeds of phanerogams. The largest proportions of phytoplankton and zooplankton in the composition of the diets are considered indicative of water column rather than benthic habitats. Debris may have been ingested concurrently with other items. Based on the phytoplankton found in the tadpole's intestines, $P$. paradoxa platensis larvae are nectonic. Consistent with our assessment based on diet, we observed these tadpoles in stationary midwater positions at night, maintaining their heads in an upward position by rapidly vibrating their tail tips. This behavior is similar to the
Xenopus mode as described by Wassersug (1973) and was also observed for Scinax acuminatus tadpoles in the same pond.

The intestinal contents of anuran tadpoles may be a good indicator of the floristic composition of the microhabitat they use. In this context, the fact that the tadpoles filter-feed continuously, may cause sudden reductions of the planktonic communities and may influence both the fauna supported directly by phytoplankton as well as for the higher trophic levels in the pond (Lajmanovich, 1998). These interpretations and the present diet analysis suggest that $P$. paradoxa platensis tadpoles could influence the planktonic communities due to the great volume of plankton they consume.

\section{Acknowledgements}

We thank Pedro Cacivio and Lucia Federico for collaborating in the field survey. Also we thank Melina Devercelli for checking the classification of algae. We are also grateful to Richard Wassersug, Jaime Bertoluci and three anonymous reviewers for their valuable comments on the manuscript.

\section{References}

ASIH and SSAR. 2001. Guidelines for use of live amphibians and reptiles in field research. Http: // www.utexas.edu/depts/asih/herpcoll.html.

APHA. 1976. Standard methods for the examination of water and wastewater. Fourteenth edition. Washington, D. C. APHA. AWWA and WPCF.

Bokermann, W. C. A. 1967. Girinos de anfíbios brasileiros 3. Sobre um girino gigante de Pseudis paradoxa (Amphibia, Pseudidae). Revista Brasileira de Biologia 27: 208-212.

Brillouin, L. 1965. Science and Information Theory. New York. Academic Press. 245 pp.

Burkart, R., N. O. Bárbaro, R. O. Sanchez, and D. Gómez, 1999. Eco-Regiones de la Argentina. Administración de Parques Nacionales (ed.), Buenos Aires.

Carnevali, R. 1994. Fitogeografía de la Provincia de Corrientes. Gobierno de la Provincia de Corrientes. $324 \mathrm{pp}$. 
Cei, J. M., 1980. Amphibians of Argentina. Monitore Zoologico Italiano, Monografía $N^{o} 2.609 \mathrm{pp}$.

Dixon, J. R., C. Mercolli and A. A. Yanosky. 1995. Some aspects of the ecology of Pseudis paradoxa from northeastern Argentina. Herpetological Review 26: 183-185.

Duré, M. and A. I. Kehr. 2001. Differential exploitation of trophic resources by two pseudid frogs from Corrientes, Argentina. Journal of Herpetology 35: 340-343.

Emerson, S. B. 1988. The giant tadpole of Pseudis paradoxa. Biological Journal of the Linnean Society 34: 93-104.

Frost, D. R. (Ed.). 1985. Amphibian Species of the World. Allen Press and the Association of Systematic Collections. Lawrence, Kansas. 732 pp.

Gallardo, J. M. and E. Varela de Olmedo. 1992. Anfibios de la República Argentina: Ecología y Comportamiento. PROFADU (CONICET).
Gosner, K. L. 1960. A simplified table for staging anuran embryos and larvae with notes on identification. Herpetologica 16: 183-190.

Hurtubia, J. 1973. Trophic diversity measurement in sympatric predatory species. Ecology 54: 885-890.

Lajmanovich, R. C. 1998. Estructura de una comunidad larval de anuros vinculada al ecosistema del río Paraná medio. Unpublished Ph.D. Thesis. Universidad Nacional de La Plata, Buenos Aires, Argentina.

Lajmanovich, R. C. 2000. Interpretación ecológica de una comunidad larvaria de anfibios anuros. Interciencia 25: 71-79.

Wassersug, R. J. 1973. Aspects of social behavior in anuran larvae. Pp. 273-297 in J. L. Vial (ed.), Evolutionary Biology of the Anurans: contemporary research on major problems. Columbia, Missouri, University of Missouri Press. 